\title{
Achieving Land Degradation Neutrality: A Robust Soil System Forms the Basis for Nature-Based Solutions
}

\author{
Saskia Keesstra ${ }^{1, *(\mathbb{D}}$, Saskia Visser ${ }^{2}$ and Margot De Cleen ${ }^{3}$ \\ 1 Wageningen Environmental Research, Wageningen University \& Research, Droevendaalsesteeg 3, \\ 6708PB Wageningen, The Netherlands \\ 2 Wageningen Corporate Strategy and Accounts, Wageningen University \& Research, Droevendaalsesteeg 1 , \\ 6708PB Wageningen, The Netherlands; saskia.visser@wur.nl \\ 3 The Ministry of Infrastructure and Watermanagement, Rijkswaterstaat, Griffioenlaan 2, \\ 3526LA Utrecht, The Netherlands; co.molenaar@rws.nl \\ * Correspondence: saskia.keesstra@wur.nl
}

check for

updates

Citation: Keesstra, S.; Visser, S.; De Cleen, M. Achieving Land Degradation Neutrality: A Robust Soil System Forms the Basis for Nature-Based Solutions. Land 2021, 10, 1300. https://doi.org/10.3390/ land10121300

Received: 24 November 2021 Accepted: 24 November 2021 Published: 26 November 2021

Publisher's Note: MDPI stays neutral with regard to jurisdictional claims in published maps and institutional affiliations.

Copyright: (c) 2021 by the authors. Licensee MDPI, Basel, Switzerland. This article is an open access article distributed under the terms and conditions of the Creative Commons Attribution (CC BY) license (https:// creativecommons.org/licenses/by/ $4.0 /)$.
The SDGs can be split into three sets. A set aiming for a sustainable economy (SDG $8,9,10$, and 12); a set related to a just and equal society (SDGs 1, 2, 3, 4, 5, 7, 11, and 16); and a set aiming for a healthy and robust biosphere $(6,13,14$, and 15). The last (SDG 17) pins the three sets together, indicating the need for partnerships, and emphasizes that the SDGs cannot be seen as individual goals but should be seen as a team working together and securing a balance between the spheres, towards a sustainable society.

The SDG we focus on in this Special Issue is sub goal SDG 15.3: 'By 2030, combat desertification, restore degraded land and soil, including land affected by desertification, drought and floods, and strive to achieve a land degradation-neutral world'; which is part of SDG 15: Life on Land. Although there has been a lot of debate about the exact definition of land degradation neutrality (LDN) by scientists as well as by policy makers, in this Special Issue we take a broad definition as given by the UNCCD as a starting point: $A$ state whereby the amount and quality of land resources, necessary to support ecosystem functions and services and enhance food security, remains stable or increases within specified temporal and spatial scales and ecosystems (https:/ / www.unccd.int/actions/achieving-land-degradationneutrality, accessed on 15 September 2020). We would like to state that LDN provides an opportunity to connect the three sets; transitioning our society from its current short-term profit-driven linear society towards a value-driven, circular, sustainable, and connected society for the long term. Xie et al. (2020) [1] showed in a bibliometric analysis that LDN can be seen as a broad topic, including processes, management, business models, and policies, which can be connected to the three levels of the SDGs and are also reflected by the papers in this Special Issue.

When examining in more detail the possible options for LDN that are described in the literature, most research has focused on the biosphere. Much attention has been given to the processes regarding soil and water interaction, and how different land uses impact land degradation. Studies such as Amare et al. (2019) [2], which focusses on gully formation in valley bottoms in Ethiopia, is exemplary for this. In addition, pure process knowledge acquisition for the different soil threats, such as the work of Pappalardo (2019) [3] on soil erosion, of Mahapatra et al. (2020) [4] on infiltration, of Amare et al. (2019 [2], 2021 [5]) on landslides, and of Visser and Sterk (2007) [6] on nutrient dynamics, are examples of this type of research.

The next step is to test the role of management in specific land use or pedo-climatic settings for LDN. To test of this type of research Lopez-Vicente et al. (2020) [7] showed the positive effect of cover crops in vineyards in a Mediterranean climate. Baker (2020) [8] discussed the best management strategies in fire affected forests in the USA; and Hussein et al. (2019) [9] presented the positive impact on agricultural yield and soil erosion as a result of deep tillage. Each study is one piece of the puzzle on how to achieve LDN for that 
specific area. However, more is needed to actually progress. Hence, beyond management, it is needed to look at the socio-economic requirements of a specific management intervention for successful implementation. Cerdà and Rodrigo-Comino (2021) [10] have analyzed the potential for more sustainable soil management in a winegrowing area. They argue that the largest challenge is not the knowledge about physical processes to reduce soil erosion, as many successful management options are known and tested (e.g., Assandri (2017) [11]; Schwilch et al. (2018) [12]; Tan et al. [13]); however, the adoption of such management strategies needs more than scientific evidence. It needs social acceptance and economic embedding.

With that, we come to the last necessary step: the embedding of sustainable management in business models and policy. Gichenje et al. (2019) [14] and Keshavarzi et al. (2019) [15] describe options for policy related to LDN. Gichenje (2019) [14] states that landuse planning, which requires the integration of different policy goals across various sectors concerned with land use, can be an effective mechanism through which decisions with respect to LDN can be coordinated. She also states that the current disjointed approach that is scattered across policy area is limiting their effectiveness. Keshavarzi (2019) [15] concluded that the design of management zones, using pedo-geomorphological information, could reduce the time and cost of sampling necessary to assess potentially degraded areas of land and allowing policy to be more effectively integrated.

Keesstra et al. (2018) [16], mentioned the need to search for holistic solutions that take into account elements from different goals to be able to find solutions that are sustainable from the perspective of the three levels of the SDGs: the biosphere, society, and economy. For finding solutions, we may also look at options that can be found in concepts like nature-based solutions and regenerative economies.

Therefore, we, as editors of the Special Issue, would like to highlight differences that the viewpoint (economy, society, or biosphere) create when designing management options. The viewpoint of 'economy' (Figure 1, top) strives for economic growth and therefore often aims for fast return of investment, resulting in quick wins. Since long stakeholder processes consume time and money, these benefits are often only for the directly involved individuals or companies (private parties). In general, the scale involved is the small local scale, e.g., a farmer's field used to its maximum capacity, or deforestation for generation of new agricultural fields, without taking into account the long-term or environmental effects.

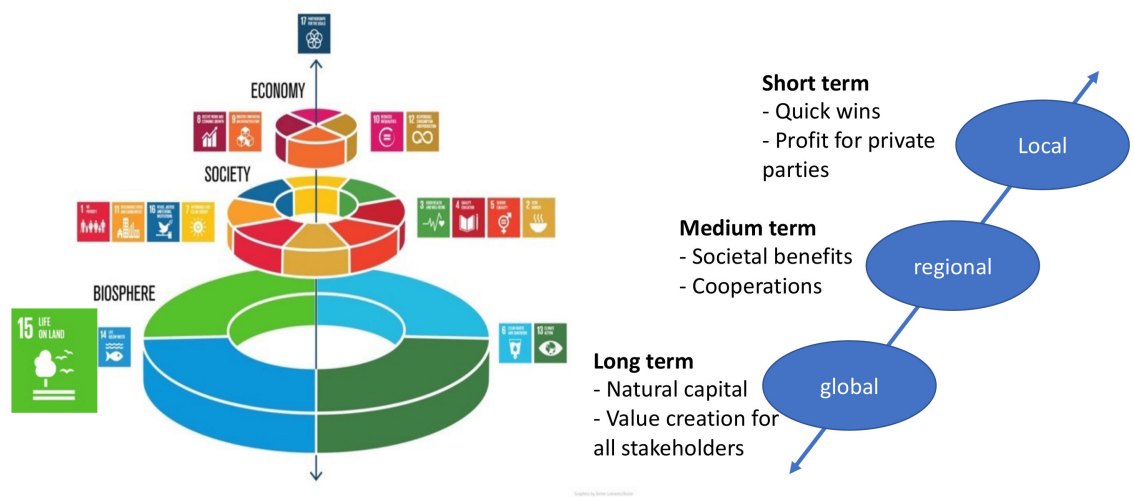

Figure 1. Scheme depicting the spatial and temporal effects and lock-ins in our current, profit-driven, linear economy, with the three sets of the SDGs (economy, society, biosphere). Left hand picture adapted after the original of the Stockholm Resilience Center.

The viewpoint of 'society' (Figure 1, middle) has a broader and longer time frame. Typically, the benefits are the groups of people that have the aim of improving society as a whole, or looking from a soil's perspective, to improve the social foundation. These groups aim to cooperate to organize and create societal benefits or values. Related to LDN, this would mean better organization of agricultural and forest activities in a specific region 
together with stakeholders with interests in other ecosystem services (water managers, drinking water companies, nature conservators, tourism).

The viewpoint of the biosphere (Figure 1, bottom) brings again a broader view. Nature needs a large timespan to act and react to a new situation. Nature management is therefore planned for a longer time frame. Large-scale nature-based solutions (NBS) that are based in landscape evolution and (dis)connectivity of water and sediment in landscapes, are good examples. The benefits and values that are related to these type of management interventions improve and sustain the ecosystem services the biosphere brings to society in the long term.

Therefore, we can observe that management interventions that have their primary objective in an economy SDG, provide benefits in the short term for the stakeholders it was targeted for. The interventions that have a societal SDG as their primary objective, usually have larger groups of stakeholders to benefit from the results and the effects have an effect for several years at the minimum. Lastly, we have the interventions that are related to the biosphere ring. These interventions usually bring benefits to the majority of stakeholders (even nature itself is a stakeholder in most cases) by improving the ecosystem services the biosphere can provide. Changes in the functioning of the biosphere usually take place over a time frame of decades. Yet, when the biosphere is taken as a fundamental basis for economics and policies (as suggested by Keshavarzi et al., (2019) [15]), the connection between the different landscape elements can be restored and values created; as a result, local management activities can contribute to large scale (potentially global) impact.

To merge the three layers, we need to focus on finding solutions that work for both the short and long term-short-term actions contributing to long-term effects. These solutions should provide the socio-economic enabling conditions and benefits for the biosphere benefits. We argue that different types of NBS may bring the necessary solutions. In the opening paper of this Special Issue by Keesstra et al. (2018) [16], the four concepts that such a solution should be based on are examined. Now, with new knowledge available, we can conclude that the NBS concepts which are based on system thinking and (dis)connectivity are the key to create a robust water-sediment-soil system that is essential to achieve LDN. The second key element is the social acceptance which can be found in the concept of a regenerative economy, which is an economic system that works to regenerate capital assets and is focused on value creation instead of short-term profit. With soil being the primary capital asset, a regenerative economy provides land a hard economic but also societal and ecological value, making it worthwhile to invest in a robust soil system.

Author Contributions: Conceptualization, S.K., S.V., and M.D.C.; resources, S.K., S.V., and M.D.C.; writing-original draft preparation, S.K., S.V., and M.D.C.; writing-review and editing, S.K., S.V., and M.D.C.; visualization, S.K., S.V., and M.D.C.; funding acquisition, S.K., S.V., and M.D.C. All authors have read and agreed to the published version of the manuscript.

Funding: The contribution of S.V. and S.K. to this research was funded by the European Union's Horizon 2020 research and innovation program EJP SOIL (grant agreement no. 869625) and by the Ministry of Agriculture, Nature, and Food through the Dutch Knowledge base program 34, "towards a circular and climate neutral society" project [KB-34-016-007]. Additionally, the sponsoring of the Ministry of Infrastructure and Water Management and the Executive Program of the Covenant Soil and Subsurface related to the Knowledge Agenda Soil and Subsurface.

Acknowledgments: We would like to thank Co Molenaar for his inspiring talk at TERRAenVISION and discussions about the LDN concept.

Conflicts of Interest: The authors declare no conflict of interest.

\section{References}

1. Xie, H.; Zhang, Y.; Wu, Z.; Lv, T. A Bibliometric Analysis on Land Degradation: Current Status, Development, and Future Directions. Land 2020, 9, 28. [CrossRef]

2. Amare, S.; Keesstra, S.; van der Ploeg, M.; Langendoen, E.; Steenhuis, T.; Tilahun, S. Causes and Controlling Factors of Valley Bottom Gullies. Land 2019, 8, 141. [CrossRef] 
3. Pappalardo, S.E.; Gislimberti, L.; Ferrarese, F.; Marchi, M.D.; Mozzi, P. Estimation of Potential Soil Erosion in the Prosecco DOCG Area (NE Italy), toward a Soil Footprint of Bottled Sparkling Wine Production in Different Land-Management Scenarios. PLoS ONE 2019, 14, e021092. [CrossRef]

4. Mahapatra, S.; Jha, M.K.; Biswal, S.; Senapati, D. Assessing Variability of Infiltration Characteristics and Reliability of Infiltration Models in a Tropical Sub-humid Region of India. Sci. Rep. 2020, 10, 1515. [CrossRef] [PubMed]

5. Amare, S.; Langendoen, E.; Keesstra, S.; van der Ploeg, M.; Gelagay, H.; Lemma, H.; van der Zee, S.E.A.T.M. Susceptibility to gully erosion: Applying random forest (RF) and frequency ratio (FR) approaches to a small catchment in Ethiopia. Water 2021, 13, 216. [CrossRef]

6. López-Vicente, M.; Calvo-Seas, E.; Álvarez, S.; Cerdà, A. Effectiveness of Cover Crops to Reduce Loss of Soil Organic Matter in a Rainfed Vineyard. Land 2020, 9, 230. [CrossRef]

7. Visser, S.M.; Sterk, G. Nutrient dynamics-Wind and water erosion at the village scale in the Sahel. Land Degrad. Dev. 2007, 18, 578-588. [CrossRef]

8. Baker, W.L. Variable Forest Structure and Fire Reconstructed Across Historical Ponderosa Pine and Mixed Conifer Landscapes of the San Juan Mountains, Colorado. Land 2020, 9, 3. [CrossRef]

9. Hussein, A.M.; Muche, H.; Schmitter, P.; Nakawuka, P.; Tilahun, S.A.; Langan, S.; Barron, J.; Steenhuis, T.S. Deep Tillage Improves Degraded Soils in the (Sub) Humid Ethiopian Highlands. Land 2019, 8, 159. [CrossRef]

10. Cerdà, A.; Rodrigo-Comino, J. Regional Farmers' Perception and Societal Issues in Vineyards Affected by High Erosion Rates. Land 2021, 10, 205. [CrossRef]

11. Assandri, G.; Bogliani, G.; Pedrini, P.; Brambilla, M. Assessing Common Birds' Ecological Requirements to Address Nature Conservation in Permanent Crops: Lessons from Italian Vineyards. J. Environ. Manag. 2017, 191, 145-154. [CrossRef] [PubMed]

12. Schwilch, G.; Lemann, T.; Berglund, Ö.; Camarotto, C.; Cerdà, A.; Daliakopoulos, I.N.; Kohnová, S.; Krzeminska, D.; Marañón, T.; Rietra, R.; et al. Assessing Impacts of Soil Management Measures on Ecosystem Services. Sustainability 2018, 10, 4416. [CrossRef]

13. Tan, Y.; Sarkar, A.; Rahman, A.; Qian, L.; Hussain Memon, W.; Magzhan, Z. Does External Shock Influence Farmer's Adoption of Modern Irrigation Technology?-A Case of Gansu Province, China. Land 2021, 10, 882. [CrossRef]

14. Gichenje, H.; Muñoz-Rojas, J.; Pinto-Correia, T. Opportunities and Limitations for Achieving Land Degradation-Neutrality through the Current Land-Use Policy Framework in Kenya. Land 2019, 8, 115. [CrossRef]

15. Keshavarzi, A.; Kumar, V.; Bottega, E.L.; Rodrigo-Comino, J. Determining Land Management Zones Using PedoGeomorphological Factors in Potential Degraded Regions to Achieve Land Degradation Neutrality. Land 2019,8 , 92. [CrossRef]

16. Keesstra, S.; Mol, G.; De Leeuw, J.; Okx, J.; Molenaar, C.; De Cleen, M.; Visser, S. Soil-Related Sustainable Development Goals: Four Concepts to Make Land Degradation Neutrality and Restoration Work. Land 2018, 7, 133. [CrossRef] 